\title{
EFFECT OF INGOT SIZE ON MICROSTRUCTURE AND PROPERTIES OF THE NEW ADVANCED AD730 ${ }^{\text {TM }}$ SUPERALLOY
}

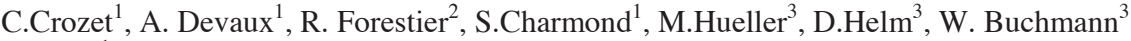 \\ ${ }^{1}$ Aubert\&Duval, Site des Ancizes BP1, 63770 Les Ancizes Cedex, France \\ ${ }^{2}$ Aubert\&Duval, Site de Pamiers, 75 bd de la Libération, 09102 Pamiers Cedex, France \\ ${ }^{3}$ MTU Aero Engines, Dachauer Str. 665, 80995 Munich, Germany
}

Keywords: AD730 ${ }^{\mathrm{TM}}$, U720Li, Ingot size, Microstructure, Mechanical properties

\begin{abstract}
The enhancement of efficiency in gas turbine engines requires the development of new superalloys capable of withstanding higher temperatures. The development of new industrial cast and wrought $(\mathrm{C} \& \mathrm{~W})$ disk alloys with required combination of strength, creep and fatigue properties at $700{ }^{\circ} \mathrm{C}$ is highly desired due to expensive cost of powder metallurgy. The development of U720Li in the nineties provided an intermediate solution in term of cost / properties combination between 718 and powder metallurgy superalloys. However, U720Li is known to be difficult to be manufactured due to its high $\gamma^{\prime}$ content (45\%) and can be considered as the limit between $\mathrm{C} \& \mathrm{~W}$ route and powder metallurgy route. Because of this and its intrinsic raw material content, U720 Li is significantly more expensive than alloy IN718. To remain competitive on worldwide aeronautical market, engine designers are more and more challenged to optimize cost/properties combination of each component. In this context, Aubert\&Duval has developed a new $\mathrm{C} \& \mathrm{~W}$ superalloy, $\mathrm{AD} 730^{\mathrm{TM}}$, which was designed to offer a better combination between high temperature properties at $700{ }^{\circ} \mathrm{C}$ and cost compared to U720 Li. The lower content of $\mathrm{Ti}$ and the lower $\gamma^{\prime}$ amount in $\mathrm{AD} 730^{\mathrm{TM}}$ compared to $\mathrm{U} 720 \mathrm{Li}$ is expected to reduce the segregation tendency. Contrary to U720Li, the better ability of $\mathrm{AD} 730^{\mathrm{TM}}$ for $\mathrm{C} \& \mathrm{~W}$ route enables the vacuum arc remelting of larger ingots up to $635 \mathrm{~mm}$ diameter, which is expected to have a beneficial impact on billet cost. This paper describes the work performed within the European Cleansky project CESAME (Cost Effective Superalloy for Advanced Modern Engine) which evaluated the feasibility of larger $\mathrm{AD} 730^{\mathrm{TM}}$ ingots (635 mm diameter ingots) in order to improve $\mathrm{AD} 730^{\mathrm{TM}}$ manufacturing cost. Comparisons between $\mathrm{AD} 730^{\mathrm{TM}}$ ingot of $635 \mathrm{~mm}$ diameter (called in the following text $\mathrm{AD} 730^{\mathrm{TM}}$ large ingot), $\mathrm{AD} 730^{\mathrm{TM}}$ ingot of $508 \mathrm{~mm}$ diameter (called in the following text $\mathrm{AD} 730^{\mathrm{TM}}$ small ingot) and U720Li ingot of $508 \mathrm{~mm}$ diameter (called in the following text U720Li ingot) were performed after conversion to billets of 254 $\mathrm{mm}$ but also on close-die forged disks. Results on billets showed that increasing ingot size for $\mathrm{AD} 730^{\mathrm{TM}}$ alloy had a beneficial impact on billet microstructure and ultrasonic testing results in comparison with $\mathrm{AD} 730^{\mathrm{TM}}$ and $\mathrm{U} 720 \mathrm{Li}$ smaller ingots $(508 \mathrm{~mm}$ diameter). Increasing $\mathrm{AD} 730^{\mathrm{TM}}$ ingot diameter up to $635 \mathrm{~mm}$ was not harmful on chemical homogeneity but led as expected to an increase of carbonitrides size. Tensile, creep and fatigue tests on close-die forged disks showed no detrimental influence of $\mathrm{AD} 730^{\mathrm{TM}}$ larger ingot size $(635 \mathrm{~mm}$ diameter $)$ compared to $\mathrm{AD} 730^{\mathrm{TM}}$ smaller ingot $(508 \mathrm{~mm}$ diameter). However, homogeneous microstructure and better UT detectability than those on $\mathrm{U} 720 \mathrm{Li}$ disks were obtained on $\mathrm{AD} 730^{\mathrm{TM}}$ disks. Mechanical properties of $\mathrm{AD} 730^{\mathrm{TM}}$ and U720Li are very similar with advantages on tensile strength at high temperature and creep
\end{abstract}

elongation for $\mathrm{AD} 730^{\mathrm{TM}}$. Finally, fatigue tests on close-die forged disks showed that the largest carbonitrides observed on disk from $\mathrm{AD} 730^{\mathrm{TM}}$ large ingot did not lead to detrimental effect on fatigue properties. This work was a reliable demonstration of $\mathrm{AD} 730^{\mathrm{TM}}$ larger ingot feasibility to enhance the combination between cost and properties.

\section{Introduction}

The latest design of high-efficiency engines has high requirements for mechanical properties and temperature capability of the key components, especially the turbine disks. Alloy development for turbine disks with higher properties and temperature capability is consequently crucial in order to improve the thermal efficiency in gas turbine engines. In addition to higher properties, manufacturing cost optimization is also one of the major criterion to select a grade for engine designers. Powder metallurgy superalloys were developed for turbine disk application to withstand a higher temperature (N18 [1], Rene88DT [2], RR1000 [3]). However, the powder metallurgy process route is significantly more expensive than the conventional cast and wrought $(\mathrm{C} \& \mathrm{~W})$ route. Consequently, powder metallurgy superalloys remain an expensive solution for disks at highest temperatures like HPT applications with a minimum of required cooling air. Development and progress were made, especially with the development of the VIM-ESR-VAR triple melt route, which enabled the manufacture of higher gamma prime fraction superalloys by the conventional $\mathrm{C} \& \mathrm{~W}$ route. In this context the alloy U720Li was developed. It is one of the highest alloyed disk materials that can be processed with the conventional $\mathrm{C} \& \mathrm{~W}$ route. This alloy exhibits an improvement in temperature capability compared to previous superalloys such as IN718 and Waspaloy [4]. Nevertheless, U720Li remains a high expensive superalloy because of its well-known industrial issues. The high contents of $\mathrm{Al}$ and Ti elements in U720Li lead to a heavy precipitation of $\gamma^{\prime}$ phase with the presence of large $\gamma / \gamma^{\prime}$ eutectic precipitates in the as-cast microstructure which are difficult to dissolve after the homogenization heat-treatment [4]. It is one of the reasons why maximum VAR ingot diameter of U720Li is commonly limited to $508 \mathrm{~mm}$. Workability issues of U720Li [4-5] require expensive forging processes with exclusively subsolvus deformation.

The new C\&W disk alloy AD730 ${ }^{\mathrm{TM}}$ developed by Aubert\&Duval was designed to offer a better combination of high temperature properties at $700{ }^{\circ} \mathrm{C}$ and cost compared to U720Li [6]. AD730 ${ }^{\mathrm{TM}}$ chemistry was designed to decrease the intrinsic raw material cost regards to $\mathrm{U} 720 \mathrm{Li}$ and to be more suitable to scraps recycling. Contrary to $\mathrm{U} 720 \mathrm{Li}, \mathrm{AD} 730^{\mathrm{TM}}$ contains $\mathrm{Nb}$ and $\mathrm{Fe}$ (Table 1) which allow recycling, for example, of IN718 or other superalloys [7]. The lower $\gamma^{\prime}$ amount in AD730 $0^{\mathrm{TM}}$, which improves the ability for the $\mathrm{C} \& \mathrm{~W}$ route, should also enable the melting of larger 
ingots. The present work was performed within the European Cleansky project CESAME (Cost Effective Superalloy for Advanced Modern Engine), to evaluate the feasibility of larger $\mathrm{AD} 730^{\mathrm{TM}}$ ingots $(635 \mathrm{~mm}$ diameter ingots) in order to improve the $\mathrm{AD} 730^{\mathrm{TM}}$ manufacturing cost. In this work, special attention was paid on properties potentially impacted by increasing ingot size such as noise level during ultrasonic inspection, macro and micro-segregation, fraction and size of carbides and nitrides, and low cycle fatigue properties. Tensile tests at elevated temperatures and creep tests were performed to precisely evaluate the effect of ingot size and fully compare $\mathrm{AD} 730^{\mathrm{TM}}$ with $\mathrm{U} 720 \mathrm{Li}$. This paper describes the results obtained with this study.

\begin{tabular}{|lcccccccccccc|}
\hline & Ni & Fe & Co & Cr & Mo & W & Al & Ti & Nb & B & C & Zr \\
\hline AD730 $^{\text {TM }}$ & Base & 4 & 8.50 & 16.0 & 3 & 2.7 & 2.3 & 3.5 & 1.1 & 0.02 & 0.02 & 0.03 \\
\hline U720Li $^{2}$ & Base & - & 15 & 16 & 3 & 1.25 & 2.5 & 5 & - & 0.02 & 0.02 & 0.03 \\
\hline
\end{tabular}

Table 1: AD730 ${ }^{\mathrm{TM}}$ and U720Li typical chemistry compositions

\section{Experimental Procedure}

Nickel base alloys AD730 ${ }^{\mathrm{TM}}$ and U720Li were used in this study (Table 1). Two AD730 ${ }^{\mathrm{TM}}$ ingots with diameters equal to $508 \mathrm{~mm}$ and $635 \mathrm{~mm}$ were remelted from the same VIM heat (Vacuum Induction Melting). In the following text, these ingots will be respectively named $\mathrm{AD} 730^{\mathrm{TM}}$ small ingot and $\mathrm{AD} 730^{\mathrm{TM}}$ large ingot. Both ingots were triple melt by Electro-Slag Remelting (ESR) and Vacuum Arc Remelting (VAR). AD730 ${ }^{\mathrm{TM}}$ ingots were then converted to $254 \mathrm{~mm}$ diameter billets. Same conversion steps were used for both ingots. Consequently, the amount of drawing deformation was more important for the billet forged from $\mathrm{AD} 730^{\mathrm{TM}}$ large ingot $(635 \mathrm{~mm}$ diameter) than that of the billet forged from $\mathrm{AD} 730^{\mathrm{TM}}$ small ingot $(508 \mathrm{~mm}$ diameter). U720Li billet of $254 \mathrm{~mm}$ diameter manufactured from triple melted 508 mm diameter ingot was supplied by Allvac company (ATI $720^{\mathrm{TM}}$ ) and was used for alloy comparison. $\mathrm{AD} 730^{\mathrm{TM}}$ billets were then forged to full scale low pressure turbine (LPT) disks (Figure 1) with an external diameter close to $500 \mathrm{~mm}$ and equivalent diameter close to $50 \mathrm{~mm}$. These disks were close-die forged below $\gamma^{\prime}$ solvus temperature in the $1050{ }^{\circ} \mathrm{C}-1090{ }^{\circ} \mathrm{C}$ temperature range. As reference, the same LPT disks were also forged from U720Li billet. AD730 ${ }^{\mathrm{TM}}$ disks were solution heat-treated at 1080 ${ }^{\circ} \mathrm{C}$ for 4 hours and then oil quenched before being aged at $730{ }^{\circ} \mathrm{C}$ for 8 hours and air cooled. U720Li disk was solution heat-treated at $1100{ }^{\circ} \mathrm{C}$ for 4 hours then oil quenched before being aged as follows $650{ }^{\circ} \mathrm{C} / 24 \mathrm{~h}+760{ }^{\circ} \mathrm{C} / 16 \mathrm{~h}$.

The vacuum arc remelting (VAR) process of $\mathrm{AD} 730^{\mathrm{TM}}$ was computed for each size of ingot by using the simulation software 'SOLAR' (which stands for SOLidification during Arc Remelting). This numerical model of the VAR process, using a finite volume method, has been developed for more than 20 years at the Nancy School of Mines (Jean Lamour Institute) [8, 9], in close collaboration with industrial partners (TIMET, CEZUS, AUBERT\&DUVAL), to simulate remelting of titanium and zirconium alloys, nickel-based superalloys and high quality special steels. This 2D-axisymetric model solves the coupled transient heat, momentum and solute transport equations, assuming a turbulent regime of the liquid metal flow in the melt pool of the remelted ingot. It is able to predict the temperature, composition and liquid pool profiles in the ingot at any time and takes into account electromagnetic stirring, buoyancy flows and turbulence effects. The mathematical model has already been validated by comparison of calculated and experimental liquid pool profiles for nickel based superalloys and special steels ingots produced by Aubert \& Duval [10, 11]. Ultrasonic Testing (UT) inspection was performed on both $\mathrm{AD} 730^{\mathrm{TM}}$ billets with the same requirements. Top and bottom slices were cut to observe the microstructure and to perform mechanical tests. Carbides distribution was established by image analysis on Olympus microscope (BX61) device and with AnalySIS software on all billets. Micro-segregation was precisely assessed by microprobe analysis (CAMECA SX100) on all billets. Around 374 chemical analyses were performed following a line type "crenel" which the length was $10 \mathrm{~mm}$ and the width of the crenel $1.7 \mathrm{~mm}$. A tension of $15 \mathrm{kV}$ with a current of $20 \mathrm{nA}$ and a LPET crystal was used for titanium analyses. The cooling rate of disks during oil quenching after solution heat-treatment was calculated in the $1050{ }^{\circ} \mathrm{C}-700$ ${ }^{\circ} \mathrm{C}$ temperature range within the disk by a Forge $(\circledR$ modeling and was estimated to be close to $220^{\circ} \mathrm{C} / \mathrm{min}$ (Figure 2). Gamma prime precipitates were observed after mechanical polishing to a mirror surface finish and selective etching using a field emission gun SEM (Supra 55).

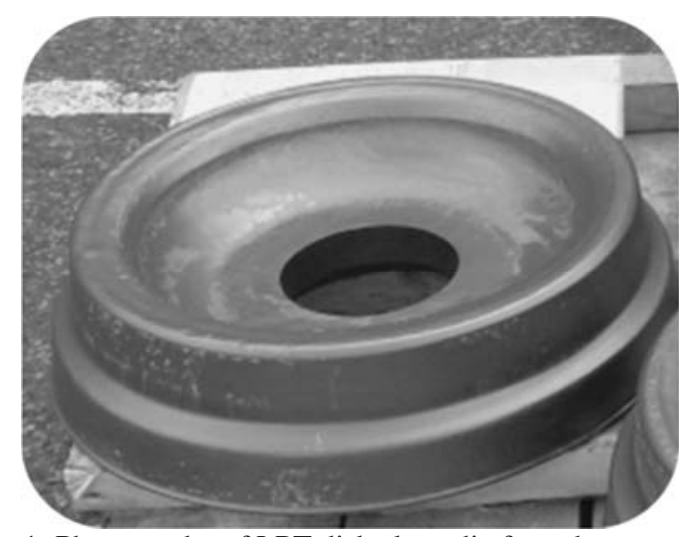

Figure 1: Photography of LPT disk close-die forged

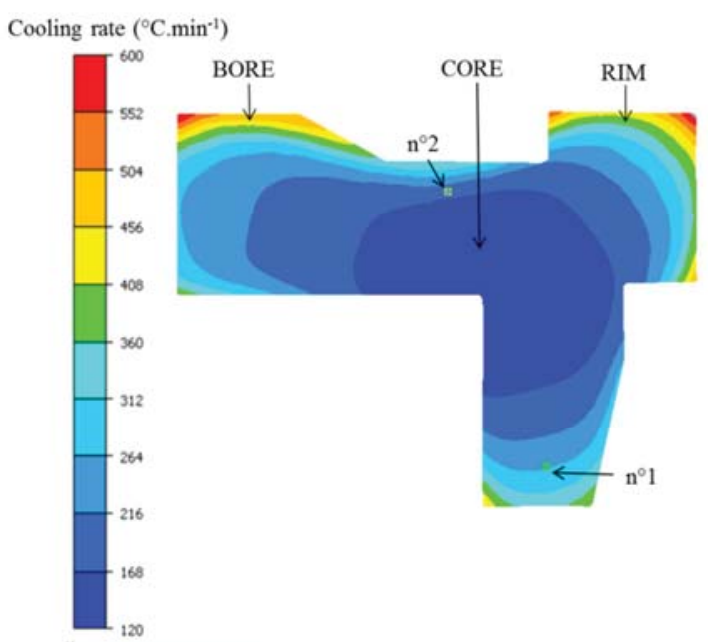

Figure 2: Cooling rate after solution heat-treatment calculated in the temperature range of $1050{ }^{\circ} \mathrm{C}-700{ }^{\circ} \mathrm{C}$ within the disk by a Forge $2 \AA$ modeling - Position $\mathrm{n}^{\circ} 1$ equal to $290{ }^{\circ} \mathrm{C} / \mathrm{min}$ and Position $\mathrm{n}^{\circ} 2$ equal to $174^{\circ} \mathrm{C} / \mathrm{min}$ 


\section{Results on billets}

The vacuum arc remelting process was modelled to evaluate the effect of ingot size and melting parameters on the solidification. Figure 3 allows the comparison of the LST (Local Solidification Time) patterns for $\mathrm{AD} 730^{\mathrm{TM}}$ small ingot and $\mathrm{AD} 730^{\mathrm{TM}}$ large ingot. The results indicate that the LST is raised by $85 \%$ for AD $730^{\mathrm{TM}}$ large ingot: from 30 minutes (AD730 ${ }^{\mathrm{TM}}$ small ingot) to 55 minutes (AD730 ${ }^{\mathrm{TM}}$ large ingot). The LST reaches its maximum value at the center location and decreases toward the periphery (Figure 4). As expected, the LST keeps growing with the ingot diameter: the surface to volume ratio gets smaller and the cooling rate is reduced. Therefore, trend to coarser structure, banding, large carbide size and freckle defect formation is more predominant when the ingot size is increased. Consequently, to evaluate the feasibility of $\mathrm{AD} 730^{\mathrm{TM}}$ large ingot, special attention was paid to chemical homogeneity within the $635 \mathrm{~mm}$ diameter ingot in order to make sure that segregation tendency was acceptable. The influence of larger ingot size on carbonitrides size was also carefully evaluated. Increasing the local solidification time on $635 \mathrm{~mm}$ diameter ingot is expected to increase the size of carbonitrides especially in the core of the billet (Figures 3 and 4) and may have an impact on the fatigue properties. Finally, microstructure and ultrasonic testing results were compared on $\mathrm{AD} 730^{\mathrm{TM}}$ materials to evaluate the influence of larger ingot size.
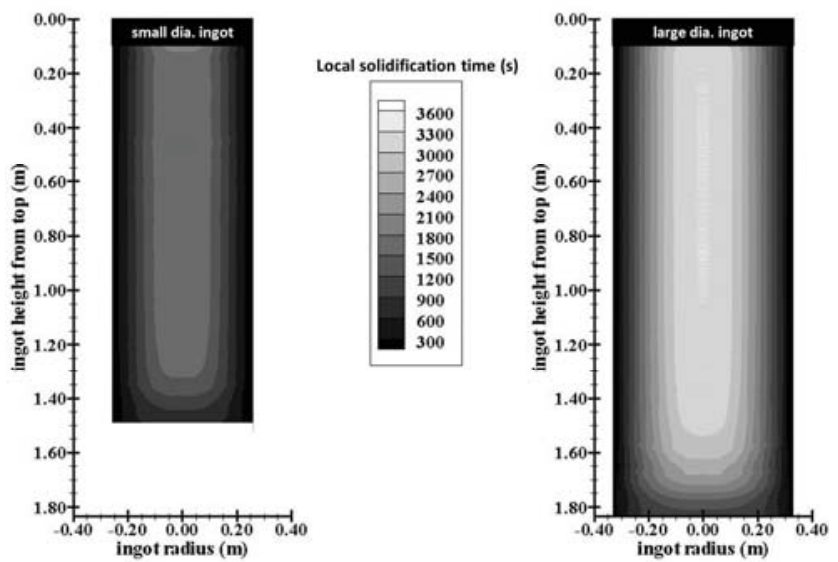

Figure 3: Modeling with Solar software of local solidification time for two size of AD730 ${ }^{\mathrm{TM}}$ ingot: $508 \mathrm{~mm}\left(\mathrm{AD} 730^{\mathrm{TM}}\right.$ small ingot) and $635 \mathrm{~mm}$ (AD730 ${ }^{\mathrm{TM}}$ large ingot ) diameters

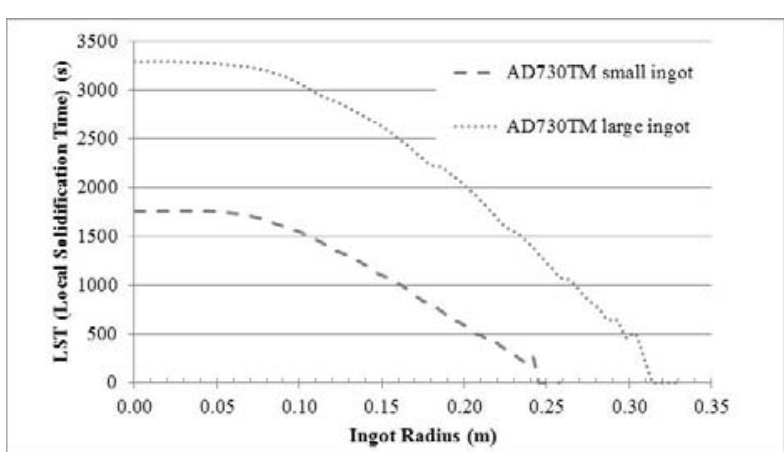

Figure 4: Modeling of local solidification time vs. Ingot radius for $\mathrm{AD} 730^{\mathrm{TM}}$ small ingot (508 mm diameter) and $\mathrm{AD} 730^{\mathrm{TM}}$ large ingot (635 $\mathrm{mm}$ diameter)

\section{Chemical homogeneity}

As shown in Table 2, chemical analyses were performed on top and bottom positions of each billet. Good chemical homogeneity is observed for both $\mathrm{AD} 730^{\mathrm{TM}}$ billets and no influence of larger ingot size was noticed. Additional assessment of chemical homogeneity was made by solution heat-treatment performed at temperatures close to the $\gamma^{\prime}$ solvus to highlight micro-segregation on both $\mathrm{AD} 730^{\mathrm{TM}}$ ingots. Same results were obtained for both ingots (Figure 5). Duplex microstructures and homogeneous coarse grains microstructure were respectively observed with solution heat-treatments at $1100{ }^{\circ} \mathrm{C}$ and $1110^{\circ} \mathrm{C}$ (Figure 5). The $\gamma^{\prime}$ solvus temperature was also measured by dilatometry on a Netzsch (402C) device. Samples $(25 \mathrm{~mm}$ in length and $3.7 \mathrm{~mm}$ in diameter) were heated up to $1160{ }^{\circ} \mathrm{C}$ and then cooled down to room temperature with a heating and cooling rate of $3{ }^{\circ} \mathrm{C} / \mathrm{min}$. For each sample, two successive cycles were made. Derivative curves for heating and cooling obtained on the second cycle are given on Figures 6 and 7. These tests show that $\gamma^{\prime}$ solvus temperatures are close to $1127^{\circ} \mathrm{C}$ for both $\mathrm{AD} 730^{\mathrm{TM}}$ ingots and that $\gamma^{\prime}$ precipitation during cooling occurs below $1082{ }^{\circ} \mathrm{C}$. Differences between $\gamma^{\prime}$ solvus temperatures determined by dilatometry tests and by heattreatment are known to be due to different heating rates which were used for the tests. All these tests clearly indicate that the chemical homogeneity of both ingots is comparable.

\begin{tabular}{|lccccccccccccc|}
\hline & & Ni & Fe & Co & Cr & Mo & W & Al & Ti & Nb & B & C & Zr \\
\hline \multirow{2}{*}{ AD730 $^{\text {TM }}$ small ingot } & Top & Base & 4.1 & 8.51 & 15.7 & 3.04 & 2.73 & 2.31 & 3.39 & 1.13 & 0.01 & 0.011 & 0.033 \\
& Bottom & Base & 4.1 & 8.50 & 15.7 & 3.04 & 2.72 & 2.3 & 3.41 & 1.13 & 0.01 & 0.011 & 0.033 \\
\hline \multirow{2}{*}{ AD730 $^{\text {TM }}$ large ingot } & Top & Base & 4.1 & 8.49 & 15.6 & 3.04 & 2.72 & 2.27 & 3.41 & 1.13 & 0.01 & 0.01 & 0.03 \\
& Bottom & Base & 4.1 & 8.50 & 15.6 & 3.03 & 2.74 & 2.29 & 3.38 & 1.12 & 0.01 & 0.01 & 0.034 \\
\hline \multirow{2}{*}{ U720Li small ingot } & Top & Base & - & 14.5 & 15.9 & 2.98 & 1.25 & 2.52 & 5.02 & - & 0.01 & 0.01 & 0.033 \\
& Bottom & Base & - & 14.5 & 15.9 & 2.98 & 1.25 & 2.54 & 5.08 & - & 0.02 & 0.01 & 0.042 \\
\hline
\end{tabular}

Table 2: Chemical composition measured on billets for the three materials 

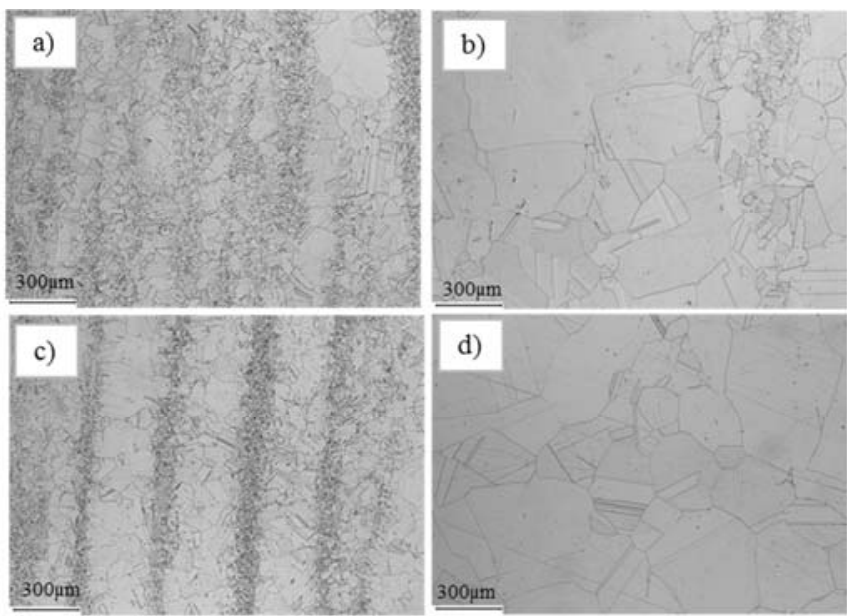

Figure 5: Microstructure obtained after heat-treatments close to $\gamma^{\prime}$ solvus - AD730 ${ }^{\mathrm{TM}}$ small ingot: a) $1100{ }^{\circ} \mathrm{C} / 4 \mathrm{~h} / \mathrm{AC}-$ b) $1110^{\circ} \mathrm{C}$ / 4h / AC - AD730 ${ }^{\mathrm{TM}}$ large ingot: c) $\left.1100{ }^{\circ} \mathrm{C} / 4 \mathrm{~h} / \mathrm{AC}-\mathrm{d}\right) 1110$ ${ }^{\circ} \mathrm{C} / 4 \mathrm{~h} / \mathrm{AC}$

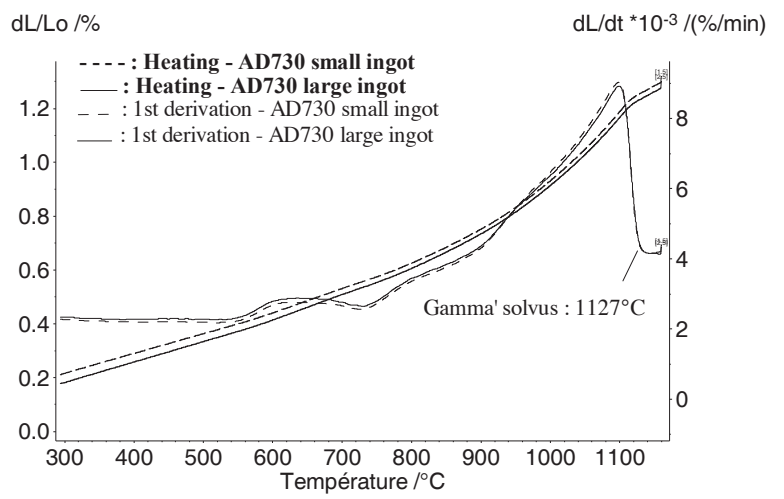

Figure 6: Dilatometry test to determine $\gamma^{\prime}$ solvus temperatures during heating

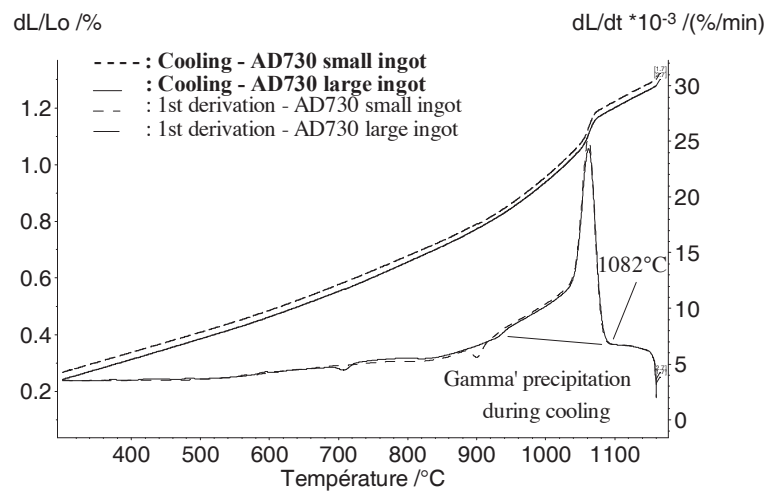

Figure 7: Dilatometry test to determine temperature range of $\gamma^{\prime}$ precipitation during cooling
Micro-segregation was also precisely assessed by microprobe analysis for the three materials. The segregation assessment was based on titanium which is the most segregated element. Results were analyzed to fit a reverse normal law and a segregation ratio, which is the ratio of standard deviation to the average value, was also calculated for each material (Figure 8). Micro-segregation of billet forged from $\mathrm{AD} 730^{\mathrm{TM}}$ large ingot was slightly higher than that of the billet forged from AD730 ${ }^{\mathrm{TM}}$ small ingot but similar to that measured on U720Li billet.

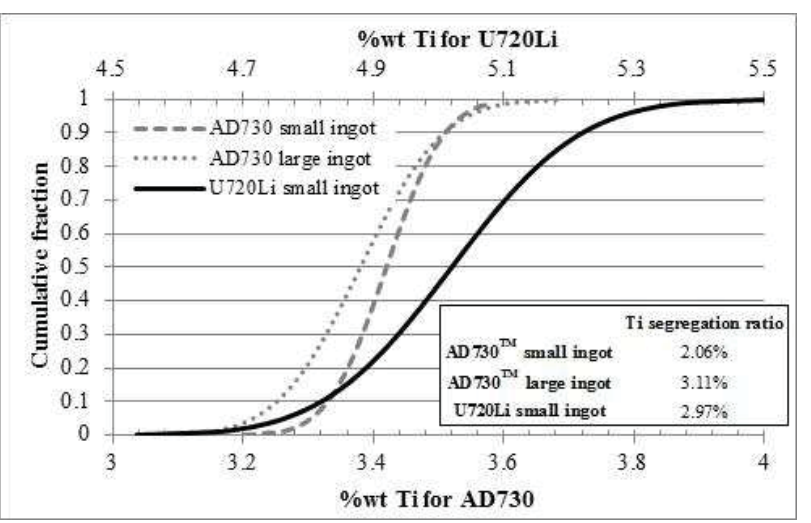

Figure 8: Cumulative fractions and segregation ratio of Ti element measured by microprobe analysis for the three materials

Carbonitrides

Carbides analyses were performed at the rim, mid-radius and center of top and bottom slices from billets. Results obtained at the center of each billet are shown in Figure 9. Largest carbonitrides were found on billet forged from $\mathrm{AD} 730^{\mathrm{TM}}$ large ingot. The effect of ingot position on carbonitrides size was evaluated with $\mathrm{AD} 730^{\mathrm{TM}}$ large ingot (Figure 10). The largest carbonitrides were measured in the top, then in the middle and finally in the bottom of the billet which is consistent with the modelling of the local solidification time (Figure 3). The local solidification time in the ingot bottom is shorter than in the top due to the high cooling effect of the VAR baseplate.

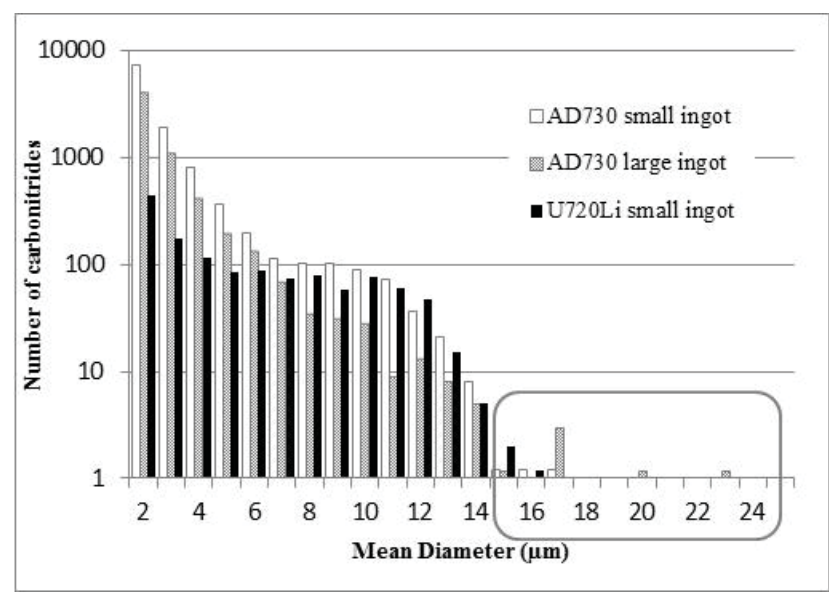

Figure 9: Carbonitrides analysis performed in the center of slices from the middle of the billets for the three materials 


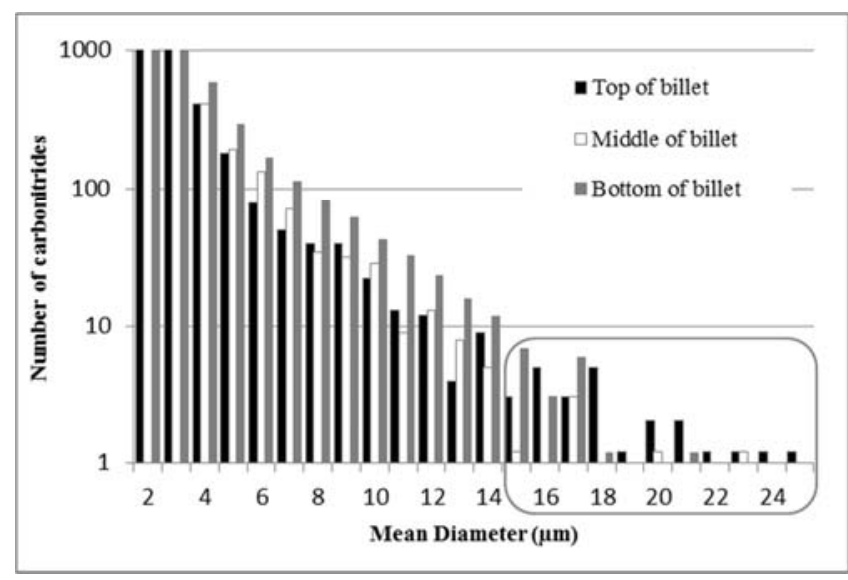

Figure 10: Carbonitrides analysis performed on billet from $\mathrm{AD} 730^{\mathrm{TM}}$ large ingot in three positions (Top, Middle, and Bottom) in the center

$\underline{\text { Sonic inspection/Microstructure }}$

Similar microstructures were observed on $\mathrm{AD} 730^{\mathrm{TM}}$ and $\mathrm{U} 720 \mathrm{Li}$ billets with an average grain size of $11 \mu \mathrm{m}$ and the presence of unrecrystallized grains (Figure 11). Nevertheless, the amount of unrecrystallized grains observed on billet from $\mathrm{AD} 730^{\mathrm{TM}}$ large ingot was much lower than those observed on billet from $\mathrm{AD} 730^{\mathrm{TM}}$ small ingot (Figure 11). The higher amount of drawing deformation used for the conversion of $635 \mathrm{~mm}$ diameter ingot to $254 \mathrm{~mm}$ diameter billet might have reduced this amount of unrecrystallized grains. This lower amount of unrecrystallized grains has also promoted a lower noise level measured by ultrasonic testing on billet.
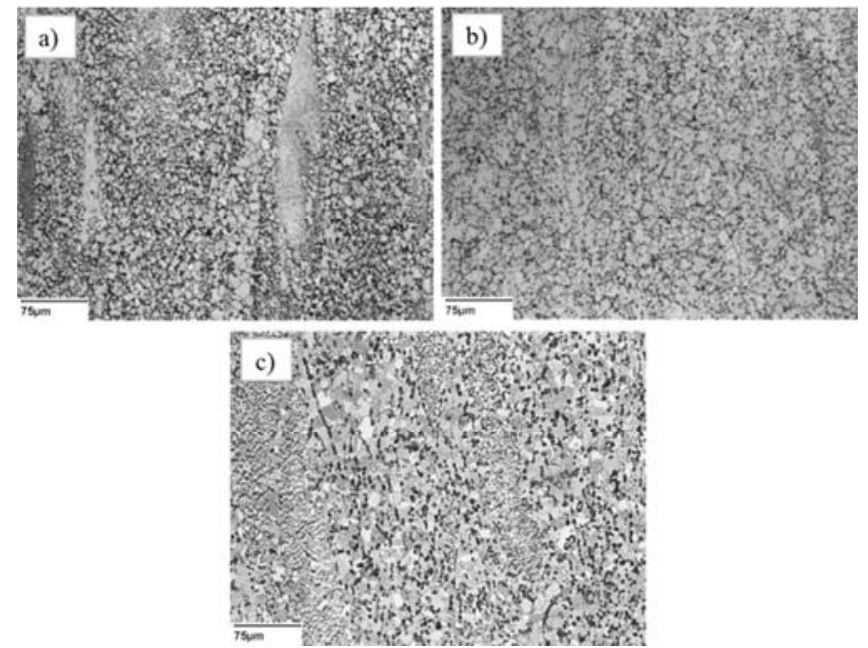

Figure 11: Microstructure observed at mid-radius of $\mathrm{AD} 730^{\mathrm{TM}}$ and U720Li: billets forged from: a) AD730 ${ }^{\mathrm{TM}}$ small ingot, b) AD730 ${ }^{\mathrm{TM}}$ large' ingots and c) U720Li small ingot

\section{Summary of billets results}

This study on billets showed that increasing ingot size for $\mathrm{AD} 730^{\mathrm{TM}}$ alloy had a beneficial impact on billet microstructure and ultrasonic testing results in comparison with $\mathrm{AD} 730^{\mathrm{TM}}$ small ingot and $\mathrm{U} 720 \mathrm{Li}$. Increasing $\mathrm{AD} 730^{\mathrm{TM}}$ ingot diameter up to 635 $\mathrm{mm}$ was not harmful on chemical homogeneity but leads as expected to an increase of carbonitrides size. The effect of $\mathrm{AD} 730^{\mathrm{TM}}$ ingot diameter and carbonitrides size on fatigue properties was evaluated on close-die forged disks to demonstrate the feasibility of $\mathrm{AD} 730^{\mathrm{TM}}$ larger ingot.

\section{Results on LPT disks}

The second step of materials comparison was achieved on LPT disks which were close-die forged from the different billets $\left(\mathrm{AD} 730^{\mathrm{TM}}\right.$ small ingot, AD730 ${ }^{\mathrm{TM}}$ large ingot and U720Li) and heat-treated.

Microstructure/gamma prime precipitation

Microstructure mappings of disk were performed on each material. Typical microstructure of $\mathrm{U} 720 \mathrm{Li}$ is a banding microstructure with areas of fine grains $(\sim 40 \mu \mathrm{m})$ and coarser grains $(\sim 110 \mu \mathrm{m})$ (Figure $12 \mathrm{c})$. AD $730^{\mathrm{TM}}$ microstructures for both disks are, on the contrary, more homogeneous than those of U720Li with only locally isolated recrystallized coarse grains containing a high gamma prime precipitates density (Figure 12a and $12 \mathrm{~b}$ ). In addition of double grain size population, U720Li disk also show isolated non-recrystallized grains of around $340 \mu \mathrm{m}$ (Figure 13) slightly larger than those observed in $\mathrm{AD} 730^{\mathrm{TM}}$ disks (ALA grain size close to $110 \mu \mathrm{m}$ ). Isolated unrecrystallized grains come from billet and are mainly localized on the upper rim of the part where the original fibers of the billet are less deformed.

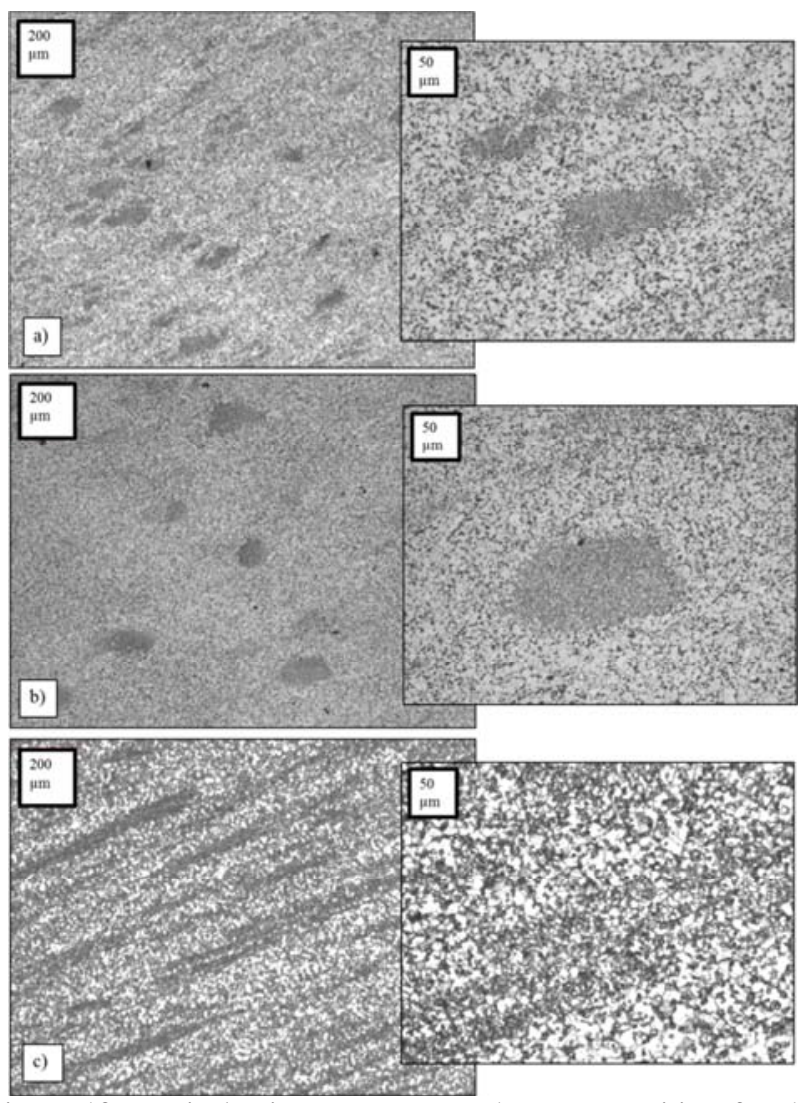

Figure 12: Typical microstructure on the same position for the three materials, on the bore of the disk: Homogeneous microstructure on $\mathrm{AD} 730^{\mathrm{TM}}$ disk a) from small ingot and b) from large ingot - c) Banded microstructures on U720Li disk 


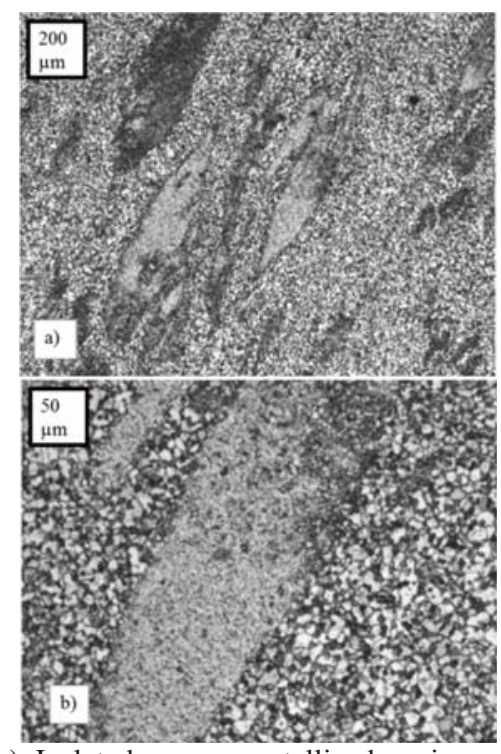

Figure 13: a) Isolated non-recrystallized grains around $340 \mu \mathrm{m}$ observed on U720Li disk - b) Focus on one unrecrystallized grain on U720Li disk

Gamma prime precipitates were observed and measured on two different positions of the disks. The first position $\left(n^{\circ} 1\right.$ Figure 2$)$ is located near the rim and the cooling rate is estimated to be equal to $290{ }^{\circ} \mathrm{C} / \mathrm{min}$. The second position ( $\mathrm{n}^{\circ} 2$ Figure 2$)$ is located near the core and the cooling rate is estimated to be equal to 174 ${ }^{\circ} \mathrm{C} / \mathrm{min}$. The secondary gamma prime precipitates sizes for the position $\mathrm{n}^{\circ} 2$ are a bit larger $(\sim 80 \mathrm{~nm})$ than those of the position $\mathrm{n}^{\circ} 1(\sim 60 \mathrm{~nm})$ (Figure 15a and $\left.\mathrm{b}\right)$. These results suggest that a slight difference of cooling rate has an impact on gamma prime precipitates. For a same position on the disk, the size of secondary gamma prime precipitates is quite similar for the three materials (Figure 16). However, in comparison with U720Li disk, a higher amount of tertiary gamma prime precipitates was observed on AD $730^{\mathrm{TM}}$ disks.

\section{UT inspection results}

Ultrasonic Testing (UT) inspection was performed on each disk with the same parameters. The maximum noise level evaluated as an equivalent flat bottom hole (EFBH) was measured on each disk (Figure 14). All the disks made from AD $730^{\mathrm{TM}}$ small ingot and AD $730^{\mathrm{TM}}$ large ingot show a lower maximum noise level than U720Li disks. These results could be related to the presence of unrecrystallized grains on U720Li disks. We can also notice the homogeneous results obtained on $\mathrm{AD} 730^{\mathrm{TM}}$ disks.

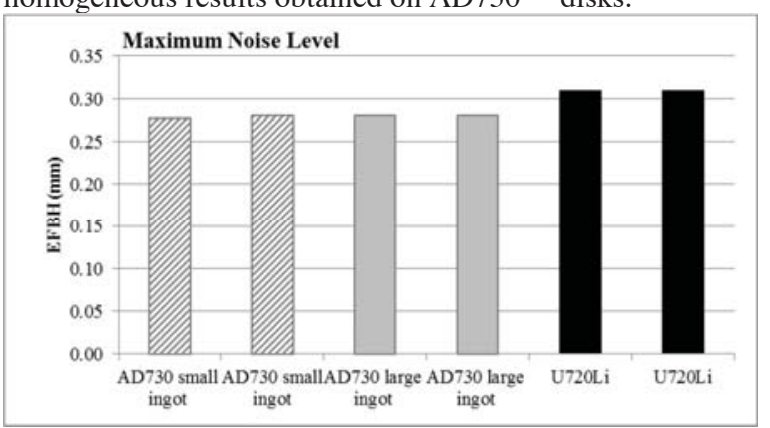

Figure 14: Maximum noise for each disk and material
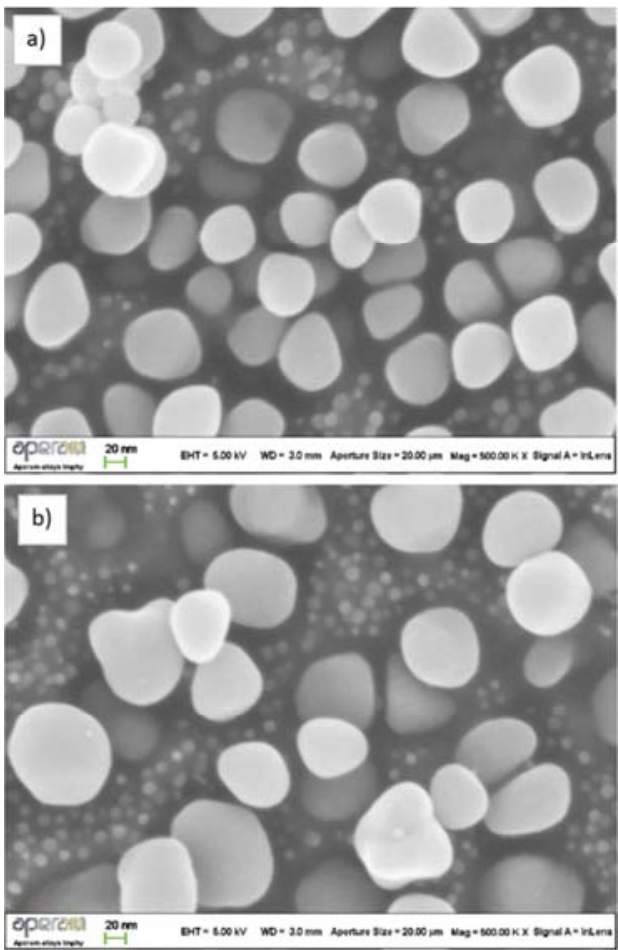

Figure 15: SEM-FEG examinations on $\gamma^{\prime}$ precipitates on $\mathrm{AD} 730^{\mathrm{TM}}$ large ingot from a) Position $\mathrm{n}^{\circ} 1$ (cooling rate $290{ }^{\circ} \mathrm{C} / \mathrm{min}$ secondary $\gamma^{\prime}$ precipitates sizes $\sim 60 \mathrm{~nm}-\mathrm{b}$ ) position $\mathrm{n}^{\circ} 2$ (cooling rate $174{ }^{\circ} \mathrm{C} / \mathrm{min}$ - secondary $\gamma^{\prime}$ precipitates sizes $\sim 80 \mathrm{~nm}$ )

\section{Tensile tests}

Ten positions in the disk were tested to obtain reliable information on mechanical properties variation. For each position, the cooling rates during quenching after solution heat-treatment were determined by numerical modelling between $1050{ }^{\circ} \mathrm{C}$ and $700{ }^{\circ} \mathrm{C}$. Tensile tests were performed at three different temperatures: room temperature (RT), $650{ }^{\circ} \mathrm{C}$ and $720^{\circ} \mathrm{C}$. All the results are given in Table 3. Tensile strength is quite homogeneous into the parts for the three billets with a maximal variation equal to $+/-50 \mathrm{MPa}$ on ultimate tensile stress (UTS) and +/-30MPa on yield stress (YS). Yield strength measurements ranked from the lowest to the highest cooling rates for the three tests temperatures are plotted on Figure 17. Higher tensile properties at high temperature are noticed for $\mathrm{AD} 730^{\mathrm{TM}}$ in comparison with $\mathrm{U} 720 \mathrm{Li}$, independently of the ingot size. These higher tensile properties could result from the higher amount of tertiary precipitates and also the higher reinforcement by refractory elements of gamma matrix [12]. At high temperature, a higher impact of the cooling rate on YS properties was observed. 

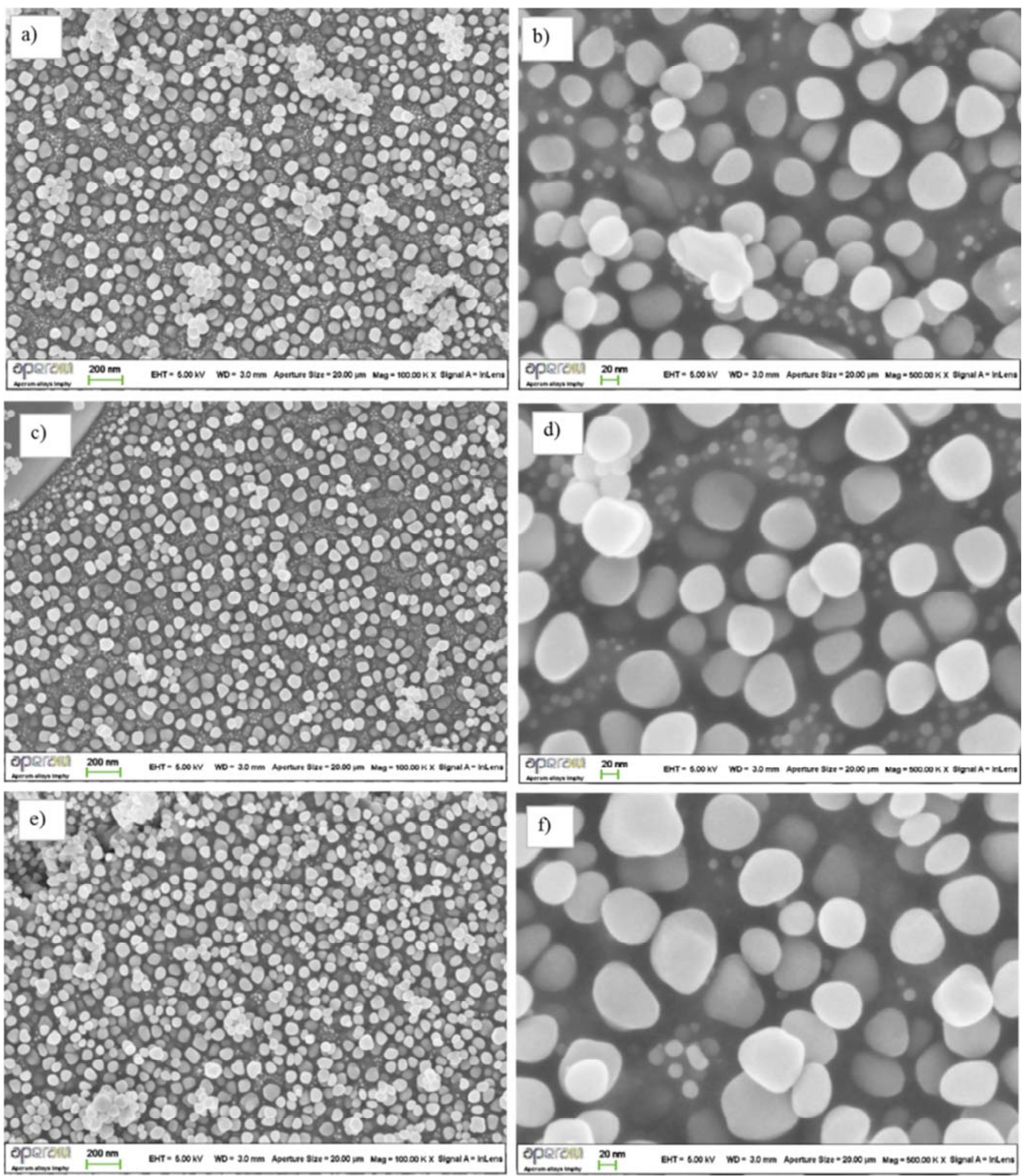

Figure 16: SEM-FEG examinations on $\gamma^{\prime}$ precipitates made on position $\mathrm{n}^{\circ} 1$ for each disk: a) and b) $\mathrm{AD} 730^{\mathrm{TM}}$ small ingot - secondary $\gamma^{\prime}$ precipitates sizes $\sim 47 \mathrm{~nm}+/-9 \mathrm{~nm}-$ c) and d) AD730 ${ }^{\mathrm{TM}}$ large ingot secondary $\gamma^{\prime}$ precipitates sizes $\sim 62 \mathrm{~nm}+/-7 \mathrm{~nm}-$ e) and f) U720Li secondary $\gamma^{\prime}$ precipitates sizes $\sim 60 \mathrm{~nm}+/-11 \mathrm{~nm}$ 


\begin{tabular}{|c|c|ccc|ccc|ccc|}
\hline \multicolumn{2}{|c|}{} & \multicolumn{3}{c|}{ AD730 small ingot } & \multicolumn{3}{c|}{ AD730 large ingot } & \multicolumn{3}{c|}{ U720Li } \\
\cline { 3 - 11 } & & RT & $650^{\circ} \mathrm{C}$ & $720^{\circ} \mathrm{C}$ & RT & $650^{\circ} \mathrm{C}$ & $720^{\circ} \mathrm{C}$ & RT & $650^{\circ} \mathrm{C}$ & $720^{\circ} \mathrm{C}$ \\
\hline UTS & Average & 1582 & 1365 & 1181 & 1587 & 1362 & 1189 & 1583 & 1330 & 1115 \\
MPa & Min & 1570 & 1336 & 1152 & 1572 & 1336 & 1167 & 1571 & 1307 & 1090 \\
& Max & 1600 & 1429 & 1215 & 1605 & 1392 & 1234 & 1591 & 1351 & 1130 \\
\hline YS & Average & 1247 & 1113 & 1096 & 1247 & 1116 & 1097 & 1113 & 1048 & 1010 \\
MPa & Min & 1230 & 1078 & 1070 & 1227 & 1093 & 1075 & 1097 & 1036 & 1026 \\
& Max & 1272 & 1140 & 1113 & 1278 & 1140 & 1127 & 1144 & 1063 & 993 \\
\hline E & Average & 23 & 24 & 15 & 21 & 20 & 13 & 22 & 30 & 22 \\
$\%$ & Min & 22 & 19 & 11 & 20 & 17 & 11 & 21 & 22 & 16 \\
& Max & 24 & 26 & 21 & 24 & 22 & 15 & 24 & 35 & 31 \\
\hline RA & Average & 25 & 28 & 20 & 20 & 25 & 17 & 21 & 37 & 28 \\
$\%$ & Min & 23 & 21 & 15 & 18 & 20 & 15 & 18 & 28 & 18 \\
& Max & 28 & 31 & 27 & 25 & 28 & 20 & 28 & 47 & 38 \\
\hline
\end{tabular}

Table 3: Tensile results on three materials obtained with 10 tests for each part
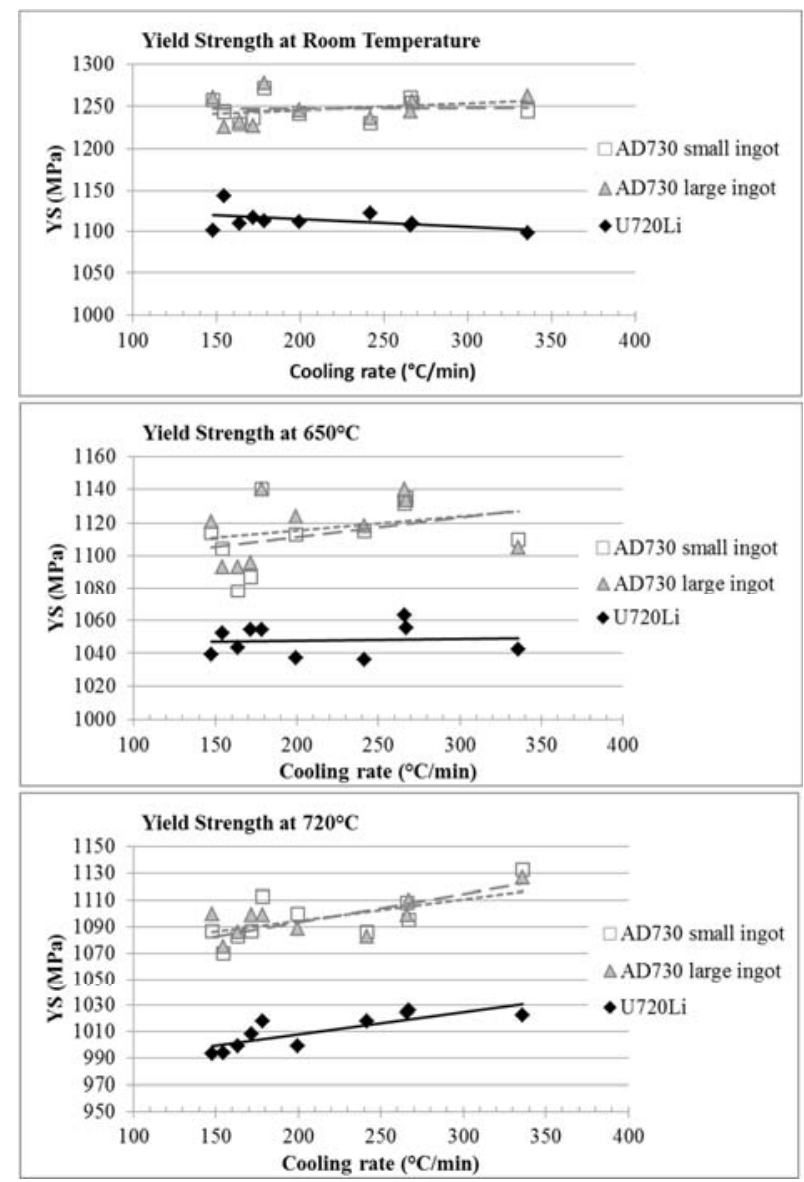

Figure 17: Tensile tests results on three materials from LPT disks
Creep tests

Four positions located in the bore and in the rim of the disk were tested in different creep conditions. Stress rupture tests performed at $720{ }^{\circ} \mathrm{C}$ under a stress equal to $500 \mathrm{MPa}$ exhibit time to rupture exceeding $200 \mathrm{~h}$ for the three materials (Figure 18). Creep tests performed at $670{ }^{\circ} \mathrm{C}$ under a stress equal to $650 \mathrm{MPa}$ confirm that creep properties of $\mathrm{AD} 730^{\mathrm{TM}}$ to be at least as good as those of U720Li (Figure 19). This better creep behavior of $\mathrm{AD}^{2} 30^{\mathrm{TM}}$ at $670{ }^{\circ} \mathrm{C}$ could result from the higher amount of tertiary precipitates and also from the higher reinforcement by refractory elements of gamma matrix [14] which both contribute to impede dislocations motion.

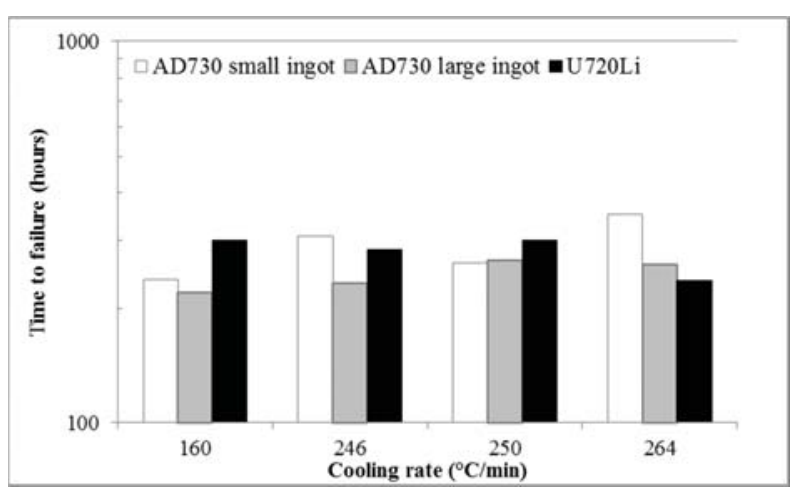

Figure 18: Stress rupture tests results performed at $720^{\circ} \mathrm{C}$ under a stress equal to $500 \mathrm{MPa}$ for the three materials 


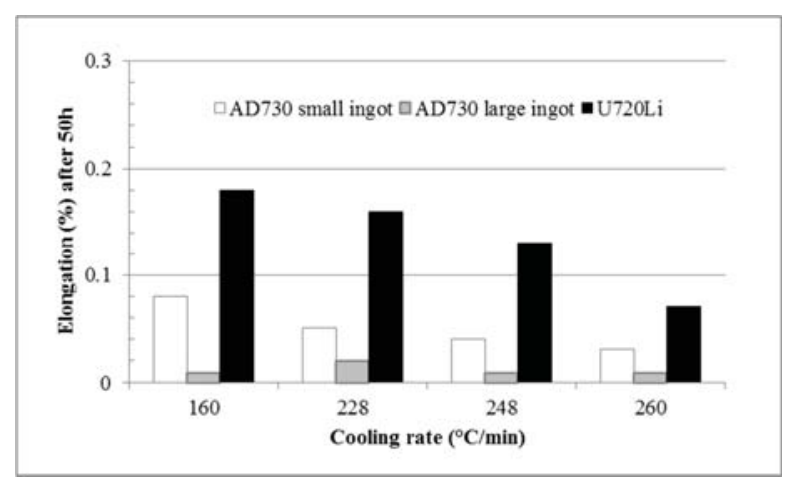

Figure 19: Creep tests results performed at $670{ }^{\circ} \mathrm{C}$ under a stress equal to $650 \mathrm{MPa}$ on three materials from LPT disks

\section{Fatigue tests}

Strain controlled LCF tests $\left(600{ }^{\circ} \mathrm{C}, \mathrm{R}=0, \varepsilon=0-0.75 \%\right)$ were performed on ten specimens cut out from each disk and the nature of all crack initiation sites were identified. Numbers of cycles to failure, ranked from the lowest to the highest cooling rate, are given in Figure 20. Good fatigue results were obtained on $\mathrm{AD} 730^{\mathrm{TM}}$ large ingot disk with fatigue lives above $1 \mathrm{E} 5$ cycles. The equivalent diameter of carbonitrides responsible for fatigue crack initiation was evaluated to be respectively close to $18 \mu \mathrm{m}$ and $24 \mu \mathrm{m}$ for disks from $\mathrm{AD} 730^{\mathrm{TM}}$ small ingot and $\mathrm{AD} 730^{\mathrm{TM}}$ large ingot (Figure 21). These results are in good agreement with the measurements made by image analysis on $\mathrm{AD} 730^{\mathrm{TM}}$ billets where the largest carbonitrides for $\mathrm{AD} 730^{\mathrm{TM}}$ small ingot and $\mathrm{AD} 730^{\mathrm{TM}}$ large ingot were measured to be respectively equal to $17 \mu \mathrm{m}$ and $23 \mu \mathrm{m}$ (Figure 9). It is noteworthy, that the lowest fatigue results (Nf below 1E5 cycles) was obtained on disk from $508 \mathrm{~mm}$ diameter ingot. Consequently, the largest carbonitrides observed on the part from $635 \mathrm{~mm}$ diameter ingot did not lead to lower fatigue properties. LCF properties of $\mathrm{AD} 730^{\mathrm{TM}}$ are quite similar to those of U720Li.

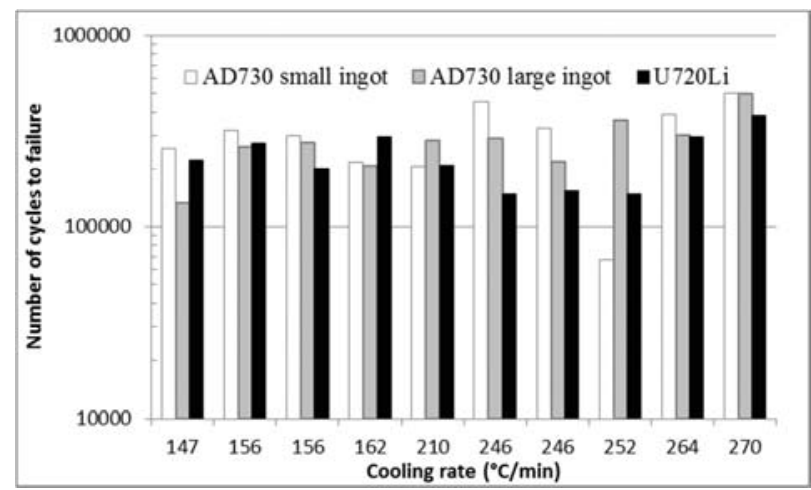

Figure 20: $\mathrm{LCF}$ tests results at $600{ }^{\circ} \mathrm{C}(\varepsilon=0-0.75 \%, \mathrm{R}=0)$ on three materials from LPT disks
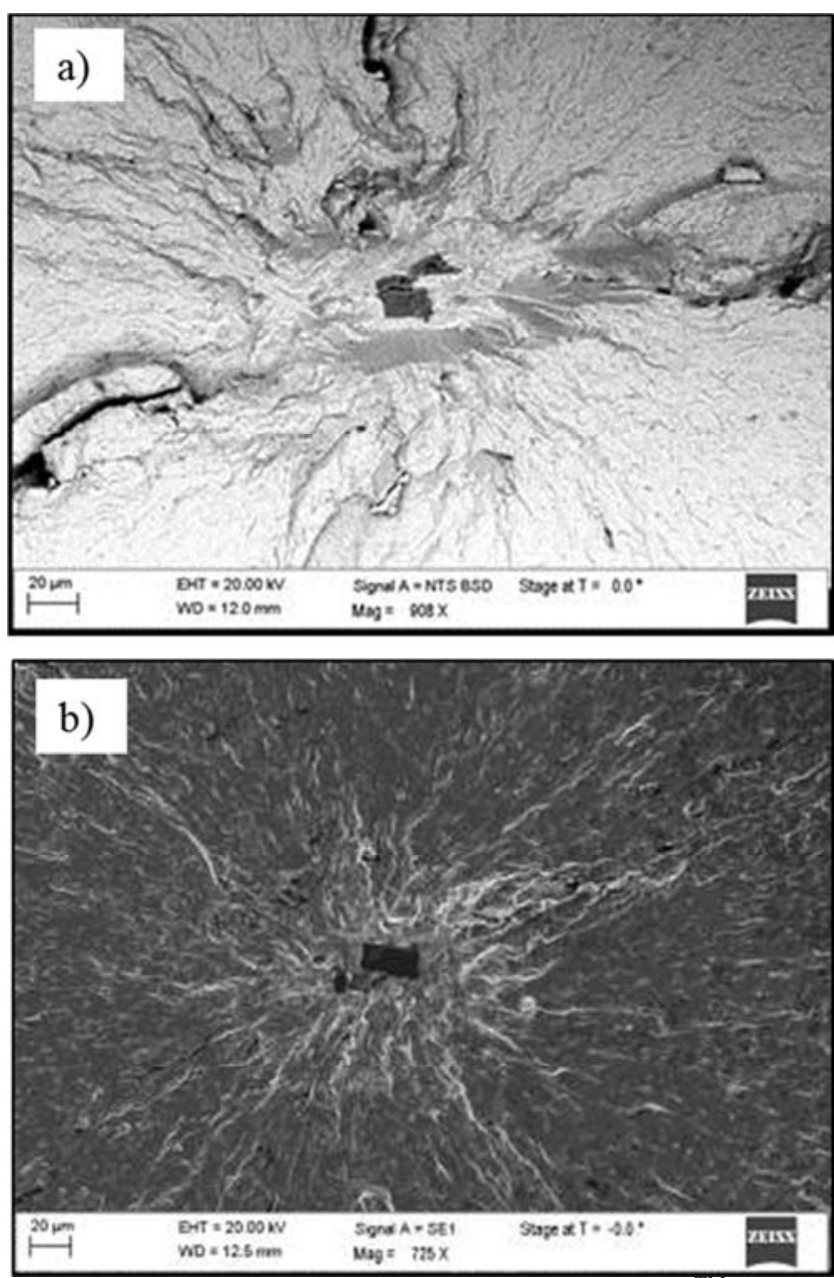

Figure 21: Example of LCF initiation sites on $\mathrm{AD} 730^{\mathrm{TM}}$ parts: a) from $\mathrm{AD} 730^{\mathrm{TM}}$ small ingot, carbonitride with $18 \mu \mathrm{m}$ mean diameter $(\mathrm{Nf}=67523) \mathrm{b})$ from $\mathrm{AD} 730^{\mathrm{TM}}$ large ingot, carbonitride with a $21.9 \mu \mathrm{m}$ mean diameter $(\mathrm{Nf}=362746)$

$\underline{\text { Summary on LPT disks results }}$

Homogeneous microstructure was obtained on $\mathrm{AD} 730^{\mathrm{TM}}$ disks compared to U720Li disk where isolated non-recrystallized coarse grains were observed. Gamma prime precipitates size is homogeneous on $\mathrm{AD} 730^{\mathrm{TM}}$ disks and a bit finer than those on U720Li disk. All the disks made from AD730 ${ }^{\mathrm{TM}}$ small and large ingots show a lower maximum noise level than those of U720Li disks. No detrimental effect of larger $\mathrm{AD} 730^{\mathrm{TM}}$ ingot diameter on mechanical properties was observed. Higher tensile properties at high temperature were obtained for $\mathrm{AD} 730^{\mathrm{TM}}$ in comparison with $\mathrm{U} 720 \mathrm{Li}$, independently of the ingot size. AD730 ${ }^{\mathrm{TM}}$ creep properties are noticed to be at least as good as those of U720Li. Fatigue tests showed that the largest carbonitrides observed on the part from $\mathrm{AD} 730^{\mathrm{TM}}$ large ingot did not lead to lower fatigue properties. 


\section{Summary/Conclusions}

This work is a reliable demonstration of $\mathrm{AD} 730^{\mathrm{TM}}$ larger ingot feasibility to enhance the combination between cost and properties. No detrimental effect of larger ingots was detected and fatigue properties as well as micro-segregations remain at a good and acceptable level. Mechanical properties of $\mathrm{AD} 730^{\mathrm{TM}}$ and U720Li are very similar. There are even advantages on tensile strength at high temperature and creep elongation for $\mathrm{AD} 730^{\mathrm{TM}}$.

\section{References}

1. C. Ducrocq, A. Lasalmonie and Y. Honnorat, "N18 - A New Damage Ttolerant PM Superalloy for High Temperature", Superalloys 1988, (1988), 63-72.

2. D.D. Krueger, R.D. Kissinger and R.G. Menzies, "Development and Introduction of a Damage Tolerant High Temperature Nickel-Base Disk Alloy - René88DT", Superalloys 1992, (1992), 277-286.

3. M.C. Hardy, B. Zirbel, G. Shen and R. Shankar, "Developing Damage Tolerance and Creep Resistance in a High Strength Nickel Alloy for Disc Applications", Superalloys 2004, (2004), 83-90.

4. A. Grellier, P. Héritier and J. Papier, "Manufacturing of Udimet720 and Properties Alloy for Aircraft Engines Applications", Matériaux et Techniques, Feb (1988), 99.

5. M. Fahrman and A. Suzuki, "Effect of Cooling Rate of Gleeble Hot Ductility of Udimet alloy 720 Billet", Superalloys 2008, (2008), 311-316

6. A. Devaux, B. Picqué, M.F. Gervais, E. Georges, T. Poulain and P. Héritier, "AD730" Superalloy for High Temperature Engine Rotative Parts", Superalloys 2012, (2012), 911-919

7. A.Devaux, E.Georges and P. Héritier, "Development of New C\&W Superalloys for High Temperature Disk Application", Advanced material Research, 278 (2011), 405-410

8. A. Jardy, S. Hans and D. Ablitzer, "A Numerical Model for the Prediction of Transient Turbulent Fluid Flow, Heat Transfer and Solidification during Vacuum Arc Remelting" (Paper presented at the International Symposium on Liquid Metal Processing and Casting, Santa Fe (NM), USA, 1994).

9. S. Hans, "Modelling of the Coupled Heat, Solute and Momentum Transfers during Vacuum Arc Remelting (VAR) Application to Titanium Alloys", (PhD. Thesis, Nancy, France, 1995).

10. T. Quatravaux, S. Rybéron, S. Hans, A. Jardy, B. Lusson and D. Ablitzer, "Transient VAR Ingot Growth Modelling, Application to Nickel based and Steel Alloys" (Paper presented at the International Symposium On Liquid Metal Processing and Casting, Nancy, France, 2003).

11. S. Hans, S. Rybéron, H. Poisson and P. Héritier, "Industrial Applications of VAR Modelling for Special Steels and Nickelbase Superalloys" (Paper presented at the International
Symposium on Liquid Metal Processing and Casting, Santa Fe (NM), USA, 2005).

12. C. Bellot and P. Lamesle, "Quantitative Measurement of Gamma Prime Precipitates in Two Industrial Nickel-based Superalloys using Extraction and High Resolution SEM Imaging", Journal of Alloys and Compounds, 570 (2013), 100-103.

\section{Acknowledgements}

Authors wish to thank the Aperam Research Center of for FEGSEM observations and Eramet Research Center for Microprobe analysis.

The authors would also like to acknowledge the financial support of CESAME project (Cleansky Project, JTI-CS-2013-1-SAGE04-020, n620103)- Cost Effective Superalloy for Advanced Modern Engine, and the partner involved. 